\title{
Flu dan Batuk, Perlukah Antibiotik?
}

\author{
Ervita Indriani, Nazmi Syahida Susanti \\ Program Sarjana Farmasi, Fakultas Farmasi, Universitas Padjadjaran, Sumedang, 45363 \\ email: shafiyyahmayya@gmail.com
}

\section{Abstrak :}

Saat ini banyak masyarakat yang tidak mengetahui pemakaian antibiotik secara tepat dan benar. Sehingga pada penyakit ringan seperti flu, batuk, pusing, dan penyakit ringan lainnya, mereka langsung menggunakan antibiotik, namun seharusnya tidak semua penyakit membutuhkan antibiotik. Kejadian resistensi bakteri berhubungan erat dengan penggunaan antibiotik yang digunakan dengan tidak tepat. Bakteri merupakan organisme bersel satu yang dapat memiliki daya adaptasi yang sangat tinggi, sehingga dapat mengakibatkan resistensi terhadap antibiotik, Hal ini merupakan respon atau hasil suatu kondisi bakteri terhadap lingkungannya, termasuk juga dengan paparan antibiotika. Antibiotik untuk membunuh bakteri tetapi sebaliknya dapat menyebabkan bakteri tersebut berkembang menjadi kebal atau sering dinamakan resisten terhadap obat antibiotik tersebut. Kejadian resistensi yang diakibatkan oleh pemakaian antibiotik yang kurang tepat bisa terjadi pada terapi flu dan batuk.

Keyword : flu, batuk, antibiotik, resistensi

\section{Pendahuluan}

Antibiotik berasal dari bahasa yunani yang terdiri dari dua kata "anti" yang berarti lawan dan "bios" yang berarti hidup, yang dapat diartikan "melawan sesuatu yang hidup". Antibiotik merupakan zat kimia yang berasal dari bakteri dan fungi, yang berkhasiat untuk mematikan maupun menghambat pertumbuhan dari kuman (Tjay dan Rahardja, 2007).

Berdasarkan spectrum kerjanya, antibiotik digolongkan menjadi:

Narrow Spectrum (Spektrum Sempit)

Antibiotik yang berspektrum sempit bekerja aktif terhadap beberapa jenis mikroba saja atau bersifat spesifik. Untuk bakteri gram positif diantaranya kanamisin, eritromisin, dan klindamisin , sedangkan bakteri gram negatif meliputi gentamisin dan streptomisin. Contoh antibiotik dengan spectrum sempit yaitu Amoxycillin dan Ampicillin.

\section{Broad Spectrum (Spektrum Luas)}

Antibiotik yang berspektrum luas bekerja aktif pada semua jenis mikroba, mikroba gram positif maupun gram negatif. Antibiotik berspektrum luas tidak baik untuk digunakan karena tidak hanya mikroba yang ingin dimatikan saja yang terbunuh melainkan mikroba yang dibutuhkan oleh tubuh pun juga ikut terbunuh. Contoh antibiotik dengan spectrum luas yaitu Sefalosporin. 


\section{Bagaimana pemakaian Antibiotik yang benar?}

Menurut WHO, 2002 tata cara pemakaian obat yang benar, anatara lain:

- Sesuai dengan gejala atau tanda penyakit

- Pengobatan berdasarkan pemerikasan yang akurat yaitu diperiksa langsung oleh Dokter.

- Dosis yang diberikan sesuai perhitungan yang tepat.

- Waktu pemberian sesuai dengan interval, misalnya untuk pemakaian tiga kali sehari dilakukan selang 8 jam.

\section{Penggunaan antibiotik seperti apa yang tidak tepat?}

Kejadian resistensi bakteri berhubungan erat dengan penggunaan antibiotik yang digunakan dengan tidak tepat. Bakteri merupakan organisme bersel satu yang dapat memiliki daya adaptasi yang sangat tinggi, sehingga dapat mengakibatkan resistensi terhadap antibiotik, Hal iini merupakan respon atau hasil suatu kondisi bakteri terhadap lingkungannya, termasuk juga dengan paparan antibiotika. Antibiotik untuk membunuh bakteri tetapi sebaliknya dapat menyebabkan bakteri tersebut berkembang menjadi kebal atau sering dinamakan resisten terhadap obat antibiotik tersebut. Penggunaan antibiotik yang dapat mengakibatkan resistensi antibiotik diantaranya:

\section{Penggunaan antibiotik secara berlebihan}

Antibiotika tidaklah bisa membunuh virus melainkan antibiotik membunuh bakteri. Namun beberapa penyakit yang kita jumpai seperti influenza, batuk, maupun diare, sebagian besar sering disebabkan oleh virus. Seringkali dokter meresepkan ataupun juga pasien berinisiatif sendiri untuk menggunakan antibiotik. Seharusnya antibiotik bisa diperlukan bila influenza dan pilek telah ditumpangi infeksi sekunder dari bakteri, itupun dapat terlihat dari adanya tanda-tanda terjadinya infeksi. Penggunaan antibiotik yang kurang tepat seperti ini dapat menyebabkan bakteri yang tadinya "lemah" akan berevolusi menjadi bakteri yang "kuat" dan menjadi resisten.

\section{Penggunaan antibiotik yang terputus/tidak habis}

Pasien sering menghentikan penggunaan obat antibiotika jika sudah merasa sembuh, padahal penggunaan antibiotikanya belum habis atau belum sampai dengan jangka waktu yang ditentukan, seperti contoh penggunaan antibiotika 5 hari atau sampai 7 hari.

Walaupun sudah merasa sembuh pasien sebaiknya menggunakan antibiotik sesuai dengan anjuran dari dokter karena penggunaan yang tidak habis akan mengakibatkan terbunuhnya bakteri yang sensitif saja sedangkan bakteri yang relatif kuat masih ada. Hal ini akan mengakibatkan bakteri yang masih hidup menjadi bakteri yang resisten atau kebal dan dapat berkembang biak serta memerlukan antibiotik yang lebih kuat dengan artian dosisnya menjadi lebih tinggi dari sebelumnya ketika pasien mengalami infeksi berikutnya.

Jika dosis digunakan kurang dari dosis efektif yang dapat menimbulkan efek terapeutik, maka obat tersebut tidak dapat menimbulkan efek terapi. 


\section{Apa itu Resistensi?}

Resistensi adalah keadaaan dimana bakteri kebal atau tidak terhambat pertumbuhannya melalui pemberian antibiotik dengan kadar dosis normal atau dosis yang seharusnya diberikan agar dapat menghambat pertumbuhan bakteri tersebut (Tripathi, 2003).

Resistensi dapat menyebabkan hilang atau menurunnya efektivitas suatu obat atau bahan kimia lainnya yang berfungsi untuk mencegah atau mengobati infeksi. Resistensi bakteri membuat bakteri tersebut kebal terhadap antibiotik yang berfungsi untuk melawannya (Bari, 2008).

\section{Resistensi antibiotik dapatkah diatasi?}

Para ilmuwan melakukan pendekatan untuk memerangi masalah mengenai resistensi terhadap antibiotik dengan menguatkan efek dari antibiotik dengan cara memodifikasi dari enzim-enzim bakteri yang dapat menyebabkan terjadinya resistensi dari antibiotik yang tidak akan menyebabkan resistensi terhadap bakteri tersebut. Ada pendekatan lain yang dilakukan untuk mengatasi reistensi terhadap antibiotik yaitu dengan cara mengintervensi mekanisme yang dapat menyebabkan terjadinya masalah resistensi, dengan tidak membunuh bakteri tersebut. Seperti, mengintervensi dengan memindahkan atau duplikasi materi genetik dari suatu bakteri dapat menghilangkan transfer dari gen-gen resisten antar suatu bakteri.

\section{Bagaimana seharusnya menggunakan antibiotik yang baik?}

Kejadian resistensi yang diakibatkan oleh pemakaian antibiotik yang kurang tepat dapat ditekan dengan melakukana hal-hal sebagai berikut :

- Dokter lebih berhati-hati dalam meresepkan obat antibiotik, jangan terlalu mudah menulis dan meresepkan obat antibiotik untuk penyakit-penyakit yang disebabkan oleh virus. Hal ini yang kemudian banyak ditiru oleh pasien atau masyarakat, di mana ketika pasien ini merasakan sakit yang diduga atau dirasa sama, dan karena dulu pernah mendapatkan resep obat antibiotika, maka pasien mencoba mengobati diri sendiri dengan menggunakan obat antibiotika tanpa resep dokter.

- Tenaga kesehatan selain dokter seperti apoteker, bidan, dan perawat, mantri, juga tidak mudah memberikan obat antibiotik kepada pasien.

- Apoteker harus lebih berhati-hati dalam memberikan/menjual resep antibiotik. Jangan memberikan/menjual obat antibiotik sembarangan tanpa adanya resep dari dokter. Janganlah menggantungkan rezeki anda dalam perbuatan ini yang nantinya akan menimbulkan bahaya bagi pasien. Jika akan menyiapkan resep obat antibiotik untuk pasien, sebaiknya apoteker memberikan edukasi secukupnya mengenai tata cara penggunaan obat antibiotiknya dengan tepat, seperti : antibiotik harus habis walaupun pasien sudah merasa sembuh, pemakaian tiga kali sehari dan lain-lain.

- Masyarakat/pasien sebaiknya tidak mudah mengobati diri sendiri dengan obat antibiotika tanpa resep dari dokter. Karena penyakit yang gejalanya sama, belum tentu obatnyapun demikian sama, sehingga sebaiknya pasien mendapatkan diagnosa terlebih dahulu yang tepat dari dokter.

- Dokter serta apoteker berperan sebagai tenaga kesehatan dapat bekerja berkesinambungan dan lebih meningkatkan komunikasi yang efektif serta lebih intens terkait dengan pemakaian dan penggunaan obat antibiotika. Apoteker yang lebih memahami mengenai obat antibiotik serta indikasinya dan kegunaannya, sedangkan dokter juga harus lebih terbuka untuk dapat diingatkan jika meresepkan antibiotika secara kurang rasional atau melebihi dosis maksimal. 


\section{Daftar Pustaka}

Tjay, T. H., dan Rahardja, K. 2007. Obat-Obat Penting Khasiat, Penggunaan, dan Efek-Efek Sampingnya. Edisi ke VI. Jakarta: PT Elex Media Komputindo: hal. 193

Tripathi, K. D. 2003. Antimicrobial drugs : general consideration. Essential of medical pharmacology. Fifth edition. Jaypee brothers medical publishers.

Bari, S. B., Mahajan, B. M., Surana, S. J. 2008. Resistance to antibiotic : A challenge in chemotherapy. Indian journal of pharmaceutical education and research.

Penuli : Ervita Indriani dan Nazmi Syahida Susanti 